\title{
Presentación. Exclusión, pobreza y TIC en las escuelas de Iberoamérica
}

\section{Apresentação. Exclusão, pobreza e TIC nas escolas da Ibero-América}

\section{Presentation. Exclusion, poverty and ICT in Latin American schools}

\author{
Joaquín Paredes-Labra1 (1) @
}

${ }^{1}$ Universidad Autónoma de Madrid, España

Los programas del modelo 1:1 de integración de computadores en las escuelas nacieron, particularmente en Iberoamérica, en la primera década del presente siglo. Se trataba de ofrecer a los estudiantes su uso individual en el aula. Aparecieron con diversos propósitos, entre los que se encuentran la mejora de la calidad de vida, en el orden social y productivo, de las comunidades y naciones donde se implantaron. Algunos de ellos, como en Uruguay, se plantearon como una iniciativa para acabar con una nueva desigualdad, originada por la brecha digital, que podría generar nuevas exclusiones. Esta misma revista se hizo eco de los primeros años de su generalización en 2011. Algunos años más tarde, con la perspectiva de una política adaptada o consolidada, se observan las oportunidades que proveen estas tecnologías que, si bien no han sido un talismán para remover la pobreza en Iberoamérica, parecen contribuir a disminuir algunos rasgos de la desigualdad, favoreciendo la inclusión y reportando mejoras a la vida de las familias de los estudiantes participantes, con base en evidencias e información recopilada.
Os programas do modelo 1:1 de integração de computadores nas escolas nasceram, particularmente na Ibero-América, na primeira década deste século. Pretendia-se oferecer aos estudantes o seu uso individual em sala de aula. Eles surgiram com diversos propósitos, entre os quais se encontra a melhoria da qualidade de vida na ordem social e produtiva das comunidades e nações onde foram implantados. Alguns deles, como no Uruguai, foram considerados uma iniciativa para acabar com uma nova desigualdade, causada pela exclusão digital, o que poderia gerar novas exclusões. Esta mesma revista ecoou os primeiros anos de sua generalização em 2011. Alguns anos mais tarde, com a perspectiva de uma política adaptada ou consolidada, verificam-se as oportunidades oferecidas por essas tecnologias que, embora não tenham sido um talismã para reduzir a pobreza na Ibero-América, parecem contribuir para diminuir alguns aspectos da desigualdade, favorecendo a inclusão e proporcionando melhorias na vida das famílias dos estudantes participantes, com base em evidências e informações coletadas. 
El monográfico se hace eco de la transformación ascendente en las telecomunicaciones en la región, mientras ocurren grandes dificultades para superar las situaciones de pobreza. En este contexto, se aprecia la popularización, en la vida cotidiana, de dispositivos de toda índole asociados al mundo digital, que conviven con políticas de mantenimiento de escuelas del modelo $1: 1$, políticas de las que se hace un balance con claroscuros, particularmente por las numerosas dificultades que han tenido que enfrentar y las adaptaciones promovidas para superarlas. También se analiza la forma en que se ha promovido el involucramiento de los docentes en el desarrollo de proyectos adaptados a sus comunidades, la vida en las escuelas en zonas deprimidas 0 con minorías étnicas y los efectos en la vida cotidiana de las familias que escolarizan a sus hijos en escuelas con el modelo $1: 1$.
Esta edição faz menção à transformação ascendente das telecomunicações na região, enquanto ocorrem grandes dificuldades para superar as situações de pobreza. Neste contexto, observa-se a popularização na vida cotidiana de dispositivos de todos os tipos associados ao mundo digital e que convivem com políticas de manutenção escolar do modelo $1: 1$, políticas das quais se realiza um balanço contrastante, principalmente pelas numerosas dificuldades que foram enfrentadas e as adaptações desenvolvidas para superá-las. Analisa-se também a maneira em que tem sido promovido o envolvimento dos professores no desenvolvimento de projetos adaptados às suas comunidades, a vida nas escolas em áreas desfavorecidas ou com minorias étnicas e os efeitos sobre o cotidiano das famílias que enviam os seus filhos para as escolas com o modelo 1:1. 